This manuscript is contextually identical with the following published paper:

Dobosy Péter, Vizsolyi Éva Cseperke, Varga Imre, Varga József, Láng Győző G., Záray Gyula (2016)

Trichloroethylene removal from water by ferrate treatment. Microchemical Journal, Volume 127, Pages 7478. doi:10.1016/j.microc.2016.02.010

The original published pdf available in this website:

http://www.sciencedirect.com/science/article/pii/S0026265X1600031X

\title{
Trichloroethylene removal from water by ferrate treatment
}

Péter Dobosy ${ }^{1,2}$ - Éva Cseperke Vizsolyi ${ }^{2,3}$ - Imre Varga ${ }^{2}$ - József Varga ${ }^{3}$ - Győző Láng ${ }^{2}$ Gyula Záray ${ }^{2 *}$

${ }^{1}$ MTA Centre for Ecological Research, Danube Research Institute, Karolina út 29-31, H-1113, Budapest, Hungary

${ }^{2}$ Cooperative Research Centre of Environmental Sciences, Eötvös Loránd University, Pázmány Péter sétány 1/A, H-1117, Budapest, Hungary

${ }^{3}$ IMSYS Ltd., Mozaik u. 14/a, H-1033, Budapest, Hungary

*Corresponding author: Gyula Záray (zaray@chem.elte.hu), Phone number: +3613722607

Keywords: groundwater, ferrate, trichloroethylene, oxidative treatment

\begin{abstract}
In this study trichloroethylene (TCE) removal from model solutions and groundwater by ferrate treatment was investigated applying different initial TCE concentrations, ferrate dosages and $\mathrm{pH}$ values. TCE concentrations were measured both in the vapor and liquid phases of water samples with head space gas chromatograph mass spectrometer (HS/GC-MS) and solid phase micro-extraction gas chromatograph mass spectrometer (SPME/GC-MS) systems, respectively. Analytical data obtained by these methods were in good agreement and
\end{abstract}


the deviations changed in the range of 1 and 7\%. The optimum $\mathrm{pH}$ value for the ferrate treatment was $\mathrm{pH}=7$. Applying ferrate in concentration of $50 \mathrm{mg} / \mathrm{L}$ for treatment of model solutions with TCE concentration of 0.1 and $1.0 \mathrm{mg} / \mathrm{L}\left(\mathrm{FeO}_{4}{ }^{2-} / \mathrm{TCE}\right.$ molar ratios 500 and 50), the removal efficiency values were 97 and 74\%, respectively. However, in case of groundwater having the same TCE concentrations but additionally $28 \mathrm{mg} / \mathrm{L}$ organic carbon content, the removal efficiency decreased to 42 and $36 \%$. It means the necessary ferrate dosage considerable depends on the chemical composition of contaminated groundwater to be treated. 


\section{Introduction}

Trichloroethylene (TCE) is a potentially carcinogenic and volatile organic chlorinated hydrocarbon (VOC), which have been used for several industrial purposes such as paint stripper, metal degreaser, chemical intermediate, and industrial cleaning agent. Due to its long-term and widespread applications, TCE became a typical contaminant both in surface and groundwater (Aulenta et al. 2005; Löffler et al. 2006).

For quantitative determination of TCE in different water matrices several sample-preparation and analytical methods are available. USEPA 551.1 Standard Method prescribes the application of liquid-liquid extraction (LLE) with methyl-tert-butyl ether or pentane. For analysis gas chromatograph (GC) coupled with electron capture detector (ECD) or mass spectrometer (MS) are recommended (Munch et al. 1995). LLE with diethyl-ether and GCMS were used to quantify TCE concentration in drinking water (Brown et al. 2003). Due to its high volatility, TCE can simply be determined with headspace (HS) GC technique or following an enrichment by solid phase micro extraction (SPME) also with GC introducing the loaded SPME fiber directly into the GC-injector port. These analytical techniques can be characterized with detection limits of 0.01-0.02 $\mu \mathrm{g} / \mathrm{L}$. (Peccorino et al. 2008; Gonzalo et al. 2008)

Over the past few decades for removal of TCE from water matrices several technologies based on biodegradation and chemical oxidation (ozone, persulfate, ferrate) have been developed. Mészáros et al. applied Sulfurospirillum halorespirans and Dehalococcoides sp. communities for biodegradation of TCE in groundwater. 95\% removal efficiency was achived and as by-products vinyl-chloride and ethane were detected (Mészáros et al. 2013). Ozonization combined with $\gamma$-radiation was also successfully applied to remove TCE from drinking water with efficiency of $98 \%$ (Gehringer et al. 1988). Liang et al. published three papers in topic of TCE removal applying activated persulfates. Depending on the activation way the TCE degradation rate changed from 65 to nearly $100 \%$ in case of model solutions (Liang et al. 2003; Liang et al 2004a; Liang et al. 2004b). Although an efficient degradation of target molecules can be achieved by oxidation technologies mentioned above, the possible by-products remain in the treated solutions. Therefore it is recommended to apply an adsorption stage (e.g. filtration through activated carbon column) after oxidation.

Ferrate technology offers a simple way for water treatment by combination of oxidation and coagulation processes (Jiang et al. 2002; Lee et al. 2004; Jiang et al. 2007). The applicability 
of ferrate for removal of heavy metals (Lim et al. 2010), cyanide (Lee et al. 2009), hydrogen sulfide (Sharma et al. 1997), ammonia (Sharma et al. 1998), arsenic (Lee et al. 2003) or organic contaminants e.g. biphenol-A (Li et al. 2008), carbohydrates (Sharma et al. 2012), phenol and chlorophenols (Graham et al. 2004), pharmaceutical residues (Sharma et al. 2006), personal care products (Yang et al. 2012) was demonstrated in the literature. It should be emphasized that the removal efficiencies were highly dependent on the testing conditions, the chemical properties of target molecules and the water matrix.

Only a few studies have been dealing with the removal of TCE by ferrate from aquatic solutions. DeLucca et al. investigated the TCE removal from model solutions containing 0.5 $\mathrm{meq} / \mathrm{L} \mathrm{NaHCO}_{3}$, about $1.0 \mathrm{mg} / \mathrm{L}$ total organic carbon (TOC) and 0.1: 0.32 and $1.0 \mathrm{mg} / \mathrm{L} \mathrm{TCE}$ by means of potassium ferrate added in concentration of 10,20 or $30 \mathrm{mg} / \mathrm{L}$ at $\mathrm{pH} 8.3$. At $\mathrm{FeO}_{4}{ }^{2-} / \mathrm{TCE}$ molar ratio of 182:1 the ferrate oxidation-coagulation processes followed by gas $\left(\mathrm{N}_{2}\right)$ flocculation resulted in practically a full removal of TCE (DeLucca et al. 1983). However, it should be noted, that during the gas flocculation a considerable amount of TCE could be volatilized. The study of Graham et al. was focused on the influence of $\mathrm{pH}$ on the degradation of TCE as a non-dissociating compound, by potassium ferrate in the $\mathrm{K}_{2} \mathrm{FeO}_{4} / \mathrm{TCE}$ molar ratio range of $1: 1$ to $9: 1$. It was established that the extent of degradation achieved a maximum at $\mathrm{pH} 8$ and about $85 \%$ of TCE was removed at molar ratio of 9:1. The lower degradation of TCE in acid or neutral conditions, where the oxidation potential of the ferrate is high, was explained by the high rate of ferrate decomposition. (Graham et al. 2004)

Nam et al. studied TCE degradation rate in model solutions with electrochemically generated ferrate at various $\mathrm{pH}$ values. According their results in case of $1.0 \mathrm{mg} / \mathrm{L}$ initial TCE concentration the removal efficiency was $64 \%$ applying potassium ferrate in concentration of $17 \mathrm{mg} / \mathrm{L} \mathrm{FeO}_{4}{ }^{2-} / \mathrm{TCE}$ molar ratio $17: 1$ at $\mathrm{pH}=7$ and treatment time of 30 minutes. As intermediate products ethyl chloride, dichloroethylene, chloroform, 1,1-dichloropropene, trichloroacetic acid, trichloroethane, and as end product $\mathrm{Cl}^{-}$were identified (Nam et al. 2012). In this work TCE removal from model solutions and spiked groundwater obtained from a chlorinated hydrocarbons contaminated area was studied using potassium ferrate solution generated by electrochemical reactions. Our goal was to develop a technology based on oxidation-coagulation processes for treatment of polluted groundwater and to select an appropriate analytical method to follow the TCE degradation comparing the HS-GC-MS and SPME-GC-MS methods. Since the contaminated groundwater has a relatively high total organic carbon content which also consumes the ferrate reagent, in our experiments a higher ferrate /TCE ratios were selected than in the papers mentioned above. 



\section{Materials and Methods}

\subsection{Chemicals}

All chemicals used during the experiment were of analytical grade. Trichloroethylene was purchased from Sigma Aldrich Ltd., Hungary, and for its dissolution ultrapure water was used produced by Milli Q Plus equipment. Potassium ferrate solution was produced by electrochemical process in our laboratory. For $\mathrm{pH}$ adjustment sulfuric acid solution and to regulate the buffer capacities of model solutions sodium-hydrogen-carbonate were applied.

\subsection{Solution preparation and handling}

Model solutions containing TCE in concentration of 0.1 and $1.0 \mathrm{mg} / \mathrm{L}$ were prepared by using ultrapure water and trichloroethylene. In order to achieve a similar buffer capacity of these solutions to the groundwater, sodium hydrogen carbonate was added in concentration of 600 $\mathrm{mg} / \mathrm{L}$ to these model solutions. In this way similar inorganic carbon content was set for both systems. Groundwater was filtered through a glass membrane (Millipore, $0.45 \mu \mathrm{m}$ ), and analyzed by methods listed in 2.4 subchapter. Since TCE was not detectable in the groundwater containing several other chlorinated hydrocarbons, TCE was added to this groundwater resulting in concentration of 0.1 and $1.0 \mathrm{mg} / \mathrm{L}$. After this process $10 \mathrm{~cm}^{3}$ of each water sample was transferred into a septum sealed vial with volume of $20 \mathrm{~cm}^{3}$.

\subsection{Analytical instruments and operating conditions}

The analysis was carried out by a Bruker SCION 436 GC-MS system, equipped with a SHS40 headspace autosampler. Separation of the compounds was obtained on a BR-5 column (30 $\mathrm{m} \times 0.25 \mathrm{~mm}, \mathrm{df}=1 \mu \mathrm{m}$ ) using helium (purity: 6.0, which means He of: $99.9999 \%$ ) as carrier gas (flow rate $2 \mathrm{ml} / \mathrm{min}$ ). The temperature of manifold, filament and transfer line was $40^{\circ} \mathrm{C}$, $200^{\circ} \mathrm{C}, 220^{\circ} \mathrm{C}$, respectively. Analytical measurements were performed in scanning mode (m/z: 50-500).

TCE concentration in the vapor phase was determined applying headspace autosampler. To achieve a steady state distribution of analyte between the vapor and liquid phase the sample was thermostated at $40^{\circ} \mathrm{C}$ for 1 minute and $1 \mathrm{~cm}^{3}$ vapor sample was injected to the GC-MS system. Column temperature program started at $60^{\circ} \mathrm{C}$ maintained for 6 minutes, then ramped at $10^{\circ} \mathrm{C} / \mathrm{min}$ up to $100^{\circ} \mathrm{C}$ (total elution time was 10 minutes). Injector temperature and split ratio were $250^{\circ} \mathrm{C}$ and $1 / 10$, respectively. 
TCE concentration in liquid phase was measured applying SPME fibers (Supelco, PDMS, 100 $\mu \mathrm{m})$. Before the first application, SPME fiber was conditioned in the GC-MS injector port at $250^{\circ} \mathrm{C}$ for $30 \mathrm{~min}$. After that the SPME fiber was introduced into the septum sealed vial containing $10 \mathrm{~cm}^{3}$ water sample and immersed into the solution at room temperature for 5 minutes, then directly injected to the GC-MS port. Between each measurement the SPME fiber was conditioned at $250^{\circ} \mathrm{C}$ for 5 minutes. GC-MS temperature program started at $40^{\circ} \mathrm{C}$ maintained for 0.75 minutes, then ramped at $20^{\circ} \mathrm{C} / \mathrm{min}$ up to $160^{\circ} \mathrm{C}$ (total elution time was $6.75 \mathrm{~min})$. Injector temperature was $230^{\circ} \mathrm{C}$ and splitless mode was used.

\subsection{Chemical analysis of groundwater}

The groundwater was obtained from a hydrocarbon contaminated area and before the treatment process its physico-chemical parameters were determined according to standard methods. Total inorganic carbon (TIC), total organic carbon (TOC), as well as total nitrogen (TN) concentrations were measured by applying a Multi N/C 2100S TC-TN analyzer (Analytik Jena, Germany) equipped with a non-dispersive infrared detector (for $\mathrm{C}$ ) and a chemiluminescent detector (for $\mathrm{N}$ ) according to the valid international standards (EN ISO 5667-3:1995 and MSZ EN 12260:2004). Specific electric conductivity and pH were characterized according to standard methods. (APHA, AWA, WEF 2005) Organic hydrocarbon content of the groundwater was identified according to HS/GC-MS method as mentioned in subchapter 2.3.

\subsection{Ferrate treatment}

$10 \mathrm{~cm}^{3}$ model solutions or spiked groundwater having 0.1 or $1.0 \mathrm{mg} / \mathrm{L}$ initial TCE concentrations were introduced into septum sealed vials. After that calculated amount of ferrate solution was added to these water samples by using an injection syringe resulting in 10, 20, 30 and $50 \mathrm{mg} / \mathrm{L}$ ferrate concentrations. Similar manner the $\mathrm{pH}$ was adjusted to 3, 5, 7, 9 or 11 by addition of sulfuric acid and the solutions were agitated with Teflon coated magnetic stirrer bar for 30 minutes. After 1 minute stabilization time the TCE concentration was measured in the vapor phase by HS-GC-MS. The TCE determination in the liquid phase by SPME-GC-MS method needed 15 minutes for sedimentation of the reduced Fe(III) compounds. 


\section{Results and discussion}

\subsection{Chemical analysis of groundwater}

Before ferrate treatment the physical-chemical parameters of groundwater: total inorganic carbon, total organic carbon, total nitrogen, $\mathrm{pH}$, specific electric conductivity were determined according to standard methods. Analytical data are listed in Table 1. As main organic hydrocarbon contaminants: 1.1 dichloroethylene, 1.2-cis dichloroethylene and 1.2-trans dichloroethyelene were identified according to above mentioned HS/GC-MS method in subchapter 2.3 .

\subsection{Optimum $\mathrm{pH}$ value establishment of ferrate treatment}

In order to establish the optimum $\mathrm{pH}$ for the ferrate treatment, model solutions having 0.1

$\mathrm{mg} / \mathrm{L}$ were reacted with ferrate at different concentration and $\mathrm{pH}$ (see subchapter 2.5). TCE concentration in the treated solutions was measured by HS/GC-MS technique. The removal efficiencies obtained at various $\mathrm{pH}$ values and ferrate concentration are presented in Fig. 1 . It can be established that the highest removal efficiency values were achieved at $\mathrm{pH}=7$ and the concentration of ferrate had only moderate influence on the TCE removal in the pH range 5-9. However, at $\mathrm{pH}=3$ and 12 , were the ferrate compounds is instable or even stabilized, respectively, the increasing ferrate concentration resulted in higher removal efficiency of TCE. Considering these results all further ferrate treatments were carried out at $\mathrm{pH}=7$.

\subsection{TCE removal from model solutions}

Model solutions having 0.1 and $1.0 \mathrm{mg} / \mathrm{L}$ TCE initial concentrations were prepared as mentioned in subchapter 2.2, and treated by ferrate at concentration of $10,20,30,50 \mathrm{mg} / \mathrm{L}$ applying intensive magnetic stirring for 30 minutes at $\mathrm{pH}=7$. After the oxidation process $\mathrm{TCE}$ residues was measured both in the vapor and the liquid phase. The removal efficiency values are illustrated in Fig 2. These analytical data demonstrate the excellent analytical features of the HS and SPME sampling procedures for determination of TCE. At $20 \mathrm{mg} / \mathrm{L}$ ferrate and 0.1 mg/L TCE concentrations 97 and 96\% removal efficiencies were measured applying these analytical methods. Increasing the TCE concentration to $1.0 \mathrm{mg} / \mathrm{L}$ the removal efficiency decreased to 74 and $73 \%$ following the same ferrate treatment. It means it is not recommended to use higher ferrate concentration than $20 \mathrm{mg} / \mathrm{L}$. 


\subsection{TCE removal from groundwater}

After chemical analysis and filtration of groundwater as mentioned in subchapter 2.2, the water samples were spiked with TCE similarly to the model solutions. Ferrate treatment process was carried out under the same conditions as in the case of model solutions. The residues of TCE were measured both in the vapor and liquid phases. The analytical results are presented in Fig 3.

It can be seen, that in presence of organic matrix compounds the TCE removal increased contrary of model solution treatment, adding more ferrate dosages, higher TCE removal can be achieved. Results demonstrate, that samples having $0.1 \mathrm{mg} / \mathrm{L}$ initial TCE concentration, in the vapor- and liquid phases removal efficiency were $42 \%$, and $41 \%$ by adding $50 \mathrm{mg} / \mathrm{L}$ ferrate dosage. Applying one magnitude higher TCE concentration and using same circumstances the degradation rate were $35 \%$ and $38 \%$, respectively. It can be seen, that in case of samples having $0.1 \mathrm{mg} / \mathrm{L}$ TCE concentration, higher removal can be achieved but it should be emphasized, that this rate is lower than in case of model solution. It can be also concluded, that similarly to treatment of model solutions the vapor and liquid phase measurements also correlated with each other.

\subsection{Comparing TCE removal efficiencies obtained for model solutions and spiked} groundwater

In Fig 4. TCE removal efficiencies are presented applying $50 \mathrm{mg} / \mathrm{L}$ ferrate concentration for treatment of model solutions and spiked groundwater having two different initial TCE concentrations.

It can be stated, that the removal efficiency decreased with increasing concentration of analyte. For example the reduction of ferrate/TCE concentration ratio from 500 to 50 resulted in removal efficiency from 97 to $74 \%$ in case of model solutions. However, this picture became more sophisticated in presence of dissolved organic and inorganic compounds which also consume the oxidation agent. Therefore the estimation of the necessary amount of ferrate for a successful purification procedure of contaminated groundwater needs a preliminary analytical investigation. First of all the TOC content plays a decisive role. 


\section{Conclusion}

Experimental data showed that both the HS/GC-MS and the SPME/GC-MS are appropriate analytical techniques to follow the concentration changes of TCE both in the contaminated and the ferrate treated groundwater samples. Comparing TCE removal from model solutions and groundwater samples, it can be concluded, that the organic groundwater matrix hampers the degradation of target molecules by oxidation. This phenomenon can be attributed to contaminants with similar or higher electron donor capacity than TCE. In order to develop an environmental friendly ferrate treatment technology for removal of TCE from contaminated groundwater in the next step the chlorine containing by-products will be identified and the chlorine balance will be calculated.

CVMBNCV,BNDFJKLGHDFLHDFLmdvndfkljbndfjklghfjkldbhoébhgtbjugfotlodfgjhjghjkl kjhhgfjfksdl 


\section{References}

APHA, AWWA, WEF (2005). Standard Methods for the Examination of Water and Wastewater, 21st ed. American Public Health Association, Washington, DC.

Aulenta F, Bianchi A, Majone M, Papini P M, Potalivo M, Tandoi V (2005) Assesment of natural or enhanced in situ bioremediation at a chlorinated solvent-contaminated aquifer in Italy: a microcosm study. Environ Int 31: 185-190.

Brown D S, Dixon M A, Bruckner V J, Bartlett G M (2003) A validated GC-MS assay for the quantitation of trichloroethylene (TCE) from drinking water. Int J Environ An Ch 83: 427-432.

DeLucca J S, Chao C A, Asce M, Smallwood C, Asce F (1983) Removal of organic priority pollutants by oxidation-coagulation. J Environ Eng 109: 36-46.

Gehringer P, Proksch E, Szinowatz W, Eshweiler H (1998) Decomposition of trichloroethylene and tetrachloroethylene in drinking water by a combined radiation/ozone treatment. Water Res 22: 645-646.

Gonzalo Lara A, Sánchez-Uría E J, Segovia-García E, Sanz-Medel A (2008) Critical comparison of automated purge and trap and solid-phase microextraction for routine determination of volatile organic compounds in drinking waters by GC-MS. Talanta 74: $1455-1462$.

Graham N, Jiang C C, Li X Z, Jiang J Q, Ma J (2004) The influence of pH on the degradation of phenol and chlorophenols by potassium ferrate. Chemosphere 56: 949-956.

Jiang J Q, Lloyd B (2002) Progress in the development and use of ferrate(VI) salt as an oxidant and coagulant for water and wastewater treatment. Water Res 36: 1397-1408.

Jiang J Q (2007) Research progress in the use of ferrate (VI) for the environmental remediation. J Hazard Mater 146: 617-623. 
Lee Y, Cho M, Kim Y J, Yoon J (2004) Chemistry of ferrate (Fe(VI)) in Aqueous Solution and its Applications as a Green Chemical. J Environ Sci Heal A 10: 161-171.

Lee Y, Um H I, Yoon J (2003) Arsenic(III) Oxidation by Iron(VI) Ferrate and Subsequent Removal of Arsenic(V) by Iron(III) Coagulation. Environ Sci Technol 37: 5750-5756.

Lee S M, Tiwari D (2009) Application of ferrate in the treatment of industrial wastes containing metal-complexed cyanides: A green treatment. J Environ Sci 21: 1347-1352.

Li C, Li X Z, Graham N, Gao N Y (2008) The aqueous degradation of bisphenol A and steroid estrogens by ferrate. Water Res 42: 109-120.

Liang C, Bruell J C, Marley C M, Sperry L K (2004) Persulfate oxidation for in situ remediation of TCE I. Activated by ferrous ion with and without a persulfate-thiosulfate redox couple. Chemosphere 55: 1213-1223.

Liang C, Bruell J C, Marley C M, Sperry L K (2004) Persulfate oxidation for in situ remediation of TCE II. Activated by chelated ferrous ion. Chemosphere 55: 1225-1233.

Liang C, Bruell J C, Marley C M, Sperry L K (2004) Thermally activated persulfate oxidation of trichloroethylene (TCE) and 1,1,1-trichloroethane (TCA) in aqueous systems and soli slurries. Soli Sediment Contam 2: 207-228.

Lim M, Kim M J (2010) Effectiveness of potassium ferrate $\left(\mathrm{K}_{2} \mathrm{FeO}_{4}\right)$ for simultaneous removal of heavy metals and natural organic maters from river water. Water Air Soil Poll 211:313-322.

Löffler E F, Edward A E (2006) Harnessing microbial activities for environmental cleanup. Curr Opin Biotech 17: 274-284.

Mészáros É, Sipos R, Pál R, Romcsis Cs, Márialigeti K (2013) Stimulation of trichloroethene biodegradation in anaerobic three-phase microcosm. Int Biodeter Biodegr 84: 126-133. 
Munch D J, Hautman D P (1995) USEPA 551.1 Determination of chlorination disinfections byproducts, chlorinated solvents, and halogenated pesticides/herbicides in drinking water by liquid-liquid extraction and gas chromatography with electron capture detector.

Nam J H, Kwon B H, Kim I K (2012) Degradation of Trichloroethylene in Aqueous Phase by Electrochemical Ferrate(VI). J Kor Soc Water Wastew 26: 453-461.

Peccorino G, Scalici L, Avellone G, Ceraulo L, Favara R, Candela G E, Provenzana C M, Scaletta C (2008) Distribution of volatile organic compounds in Sicilian groundwaters analysed by head space-solid phase micro extraction coupled with gas chromatography mass spectrometry (SPME/GC/MS). Water Res 42: 3563-3577.

Sharma K V, Smith O J, Millero F J (1997) Ferrate(VI) oxidation of hydrogen sulfide. Environ Sci Technol 31: 2486-2491.

Sharma K V, Bloom T J, Joshi V N (1998) Oxidation of ammonia by ferrate (VI). J Environ Sci Heal A 33 635-650.

Sharma K V, Mishra K S (2006) Ferrate(VI) Oxidation of Ibuprofen: A kinetic study. Environ Chem Lett 3 182-185.

Sharma V K, Sohn M, Anquandah K A G, Nesnas N (2012) Kinetics of the oxidation of sucralose and related carbohydrates by ferrate(VI). Chemosphere 87: 644-648.

Yang B, Ying B B, Zhao j L, Liu S, Zhou j L, Chen F (2012) Removal of selected endocrine disrupting chemicals (EDCs) and pharmaceutical and personal care products (PPCPs) during ferrate(VI) treatment of secondary wastewater effluents. Water Res 46: 2194-2204. 
Table 1. Physical-chemical parameters of groundwater

\begin{tabular}{|c|c|}
\hline Total inorganic carbon $(\mathrm{mg} / \mathrm{L})$ & 91.7 \\
\hline Total organic carbon $(\mathrm{mg} / \mathrm{L})$ & 28.0 \\
\hline Total nitrogen $(\mathrm{mg} / \mathrm{L})$ & 4.5 \\
\hline $\mathrm{pH}$ & 8.16 \\
\hline Specific electric conductivity $\left(\mu \mathrm{S} / \mathrm{cm}, 20^{\circ} \mathrm{C}\right)$ & 1034 \\
\hline
\end{tabular}


Fig 1.

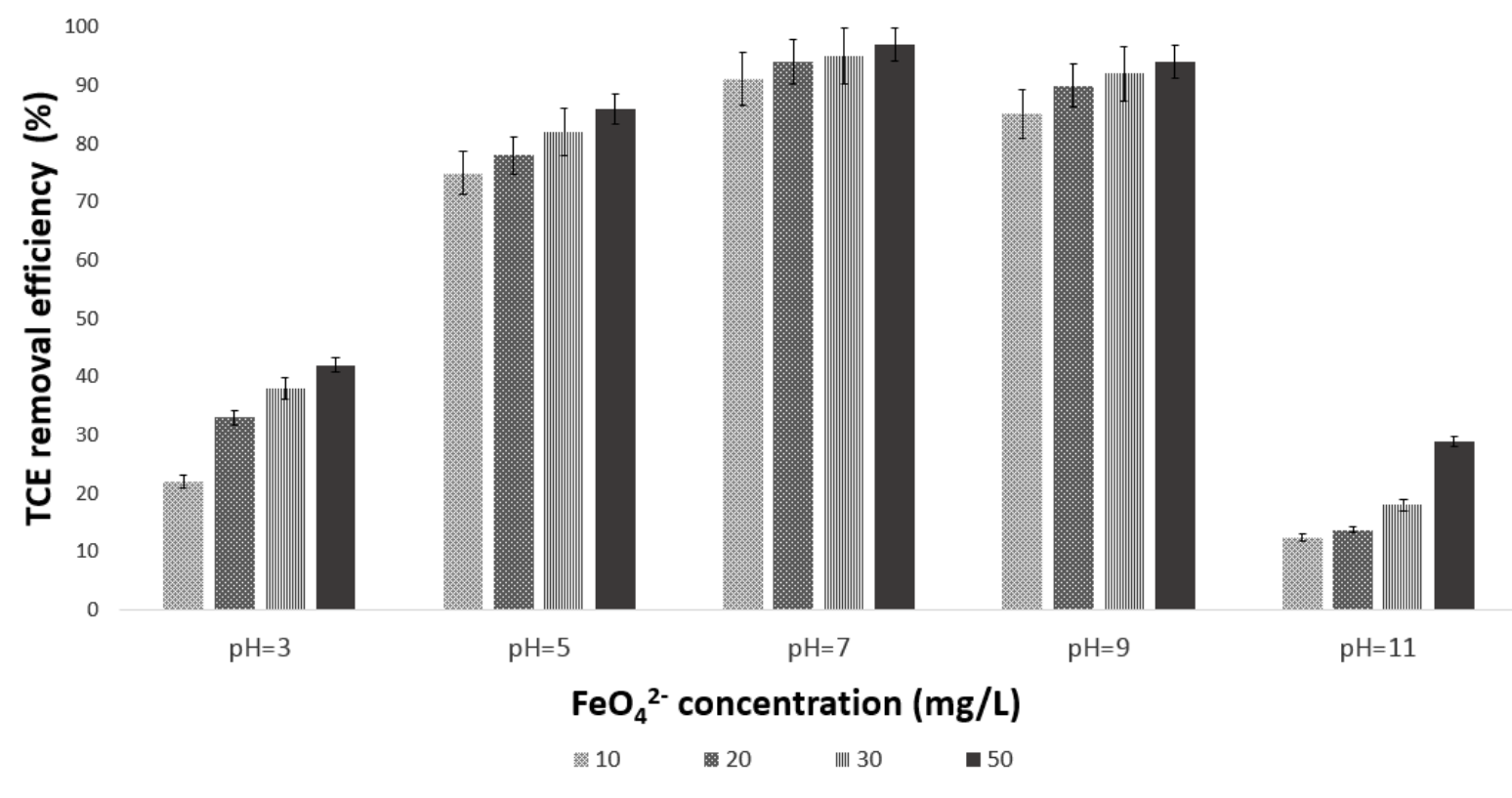


Fig. 2.

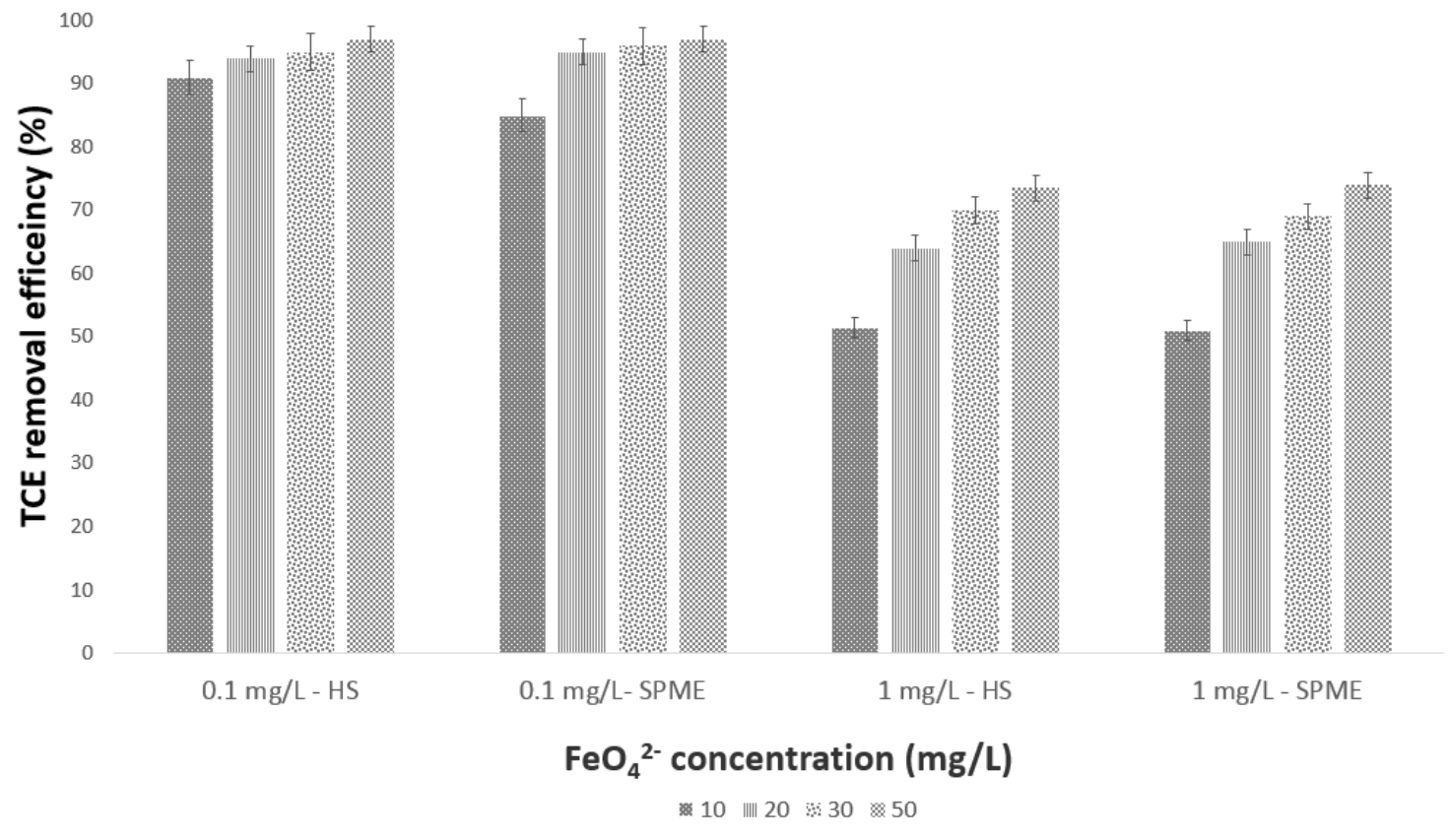


Fig.3.

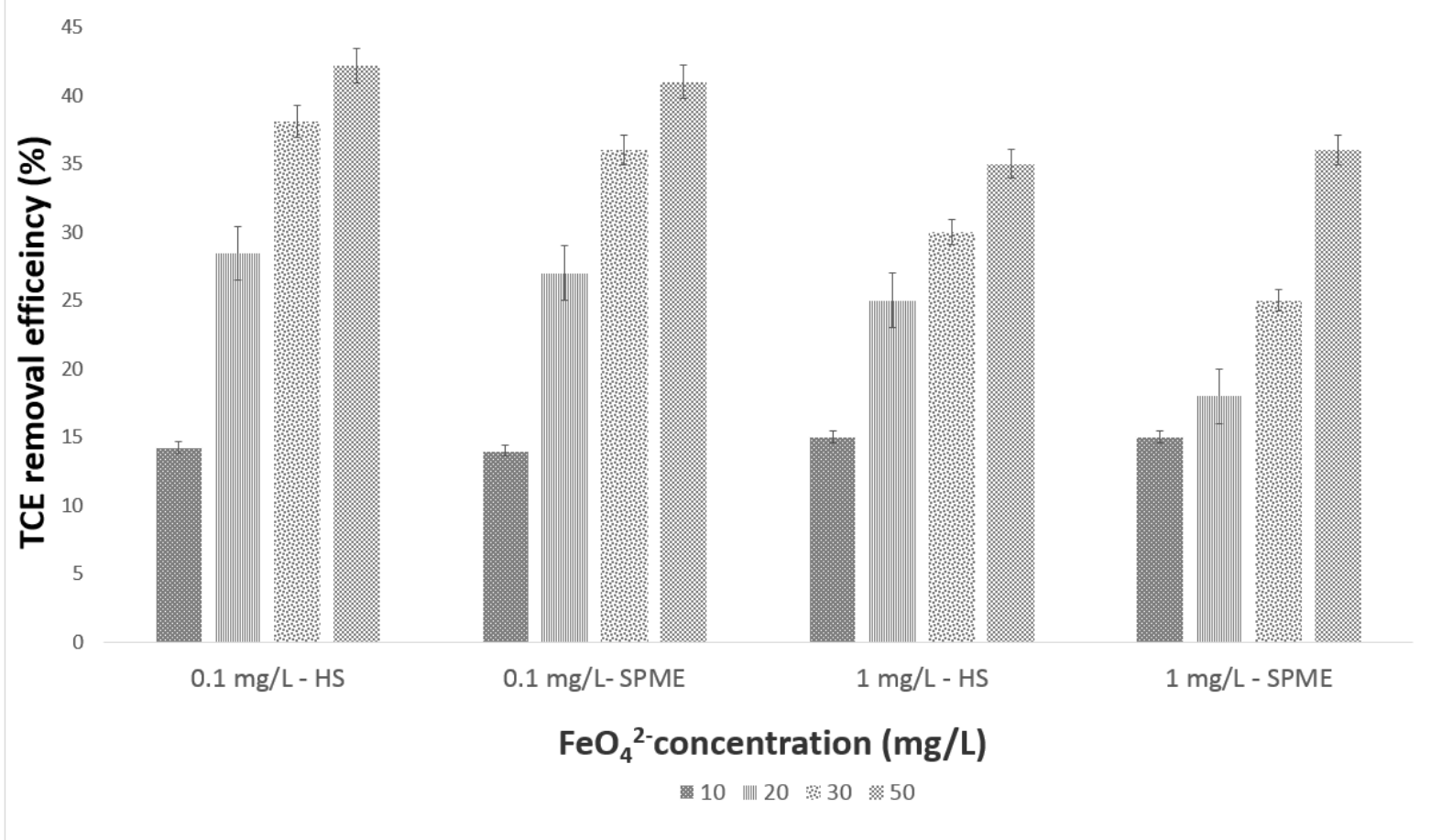


Fig. 4.

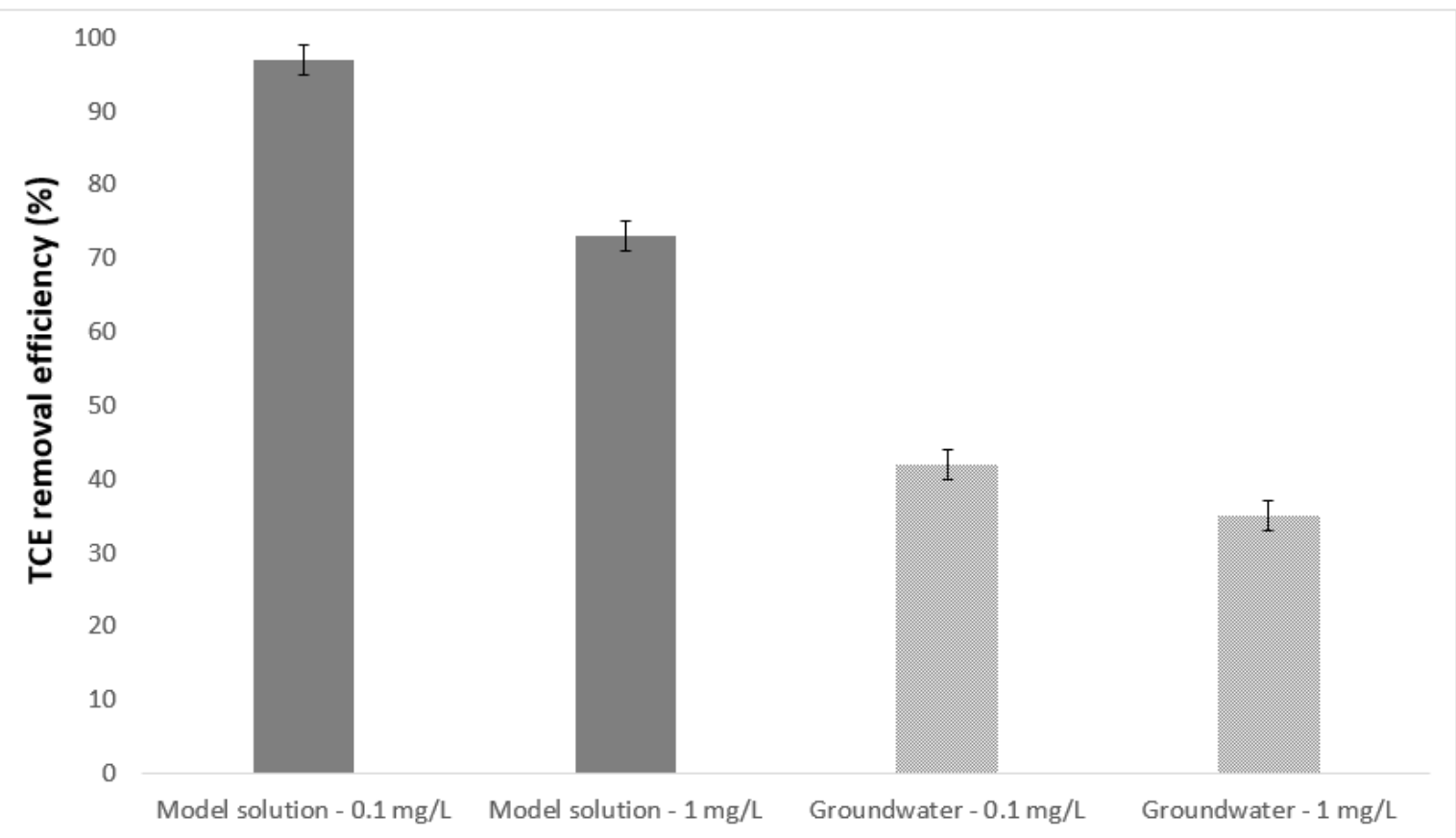




\section{$\underline{\text { Figure captions }}$}

Fig. 1. TCE removal efficiency from model solution containing TCE in concentration of 0.1 $\mathrm{mg} / \mathrm{L}$ at various $\mathrm{pH}$ and ferrate dosages; Analytical data were determined by HS-GCMS

Fig. 2. TCE removal efficiency from model solutions having 0.1 and $1.0 \mathrm{mg} / \mathrm{L}$ initial TCE concentrations at $\mathrm{pH}=7$ and various ferrate dosages; Analytical data were measured by both HS-GC-MS and SPME-GC-MS methods

Fig. 3. TCE removal efficiency from spiked groundwater containing 0.1 and $1.0 \mathrm{mg} / \mathrm{L}$ TCE at $\mathrm{pH}=7$ and various ferrate dosages; Analytical data were measured by both HS-GC-MS and SPME-GC-MS methods

Fig. 4. TCE removal efficiency from model solutions and spiked groundwater at $\mathrm{pH}=7$ and ferrate concentration of $50 \mathrm{mg} / \mathrm{L}$ measured by HS-GC-MS 